\title{
Seasonal Incidence of Different Sucking Pests of Chilli and their Natural Enemies under West Bengal Condition
}

\author{
Subhashree Priyadarshini ${ }^{1 *}$, Ashima Mishra ${ }^{2}$, Anjan Kumar Nayak ${ }^{2}$ and \\ Pavan Thakoor ${ }^{2}$ \\ ${ }^{1}$ Department of Agricultural Entomology, Professor Jayashankar Telangana State \\ Agricultural University, Hyderabad-500030, Telangana, India \\ ${ }^{2}$ Department of Agricultural Entomology, Bidhan Chandra Krishi Viswavidyalaya, \\ West Bengal-741235, India \\ *Corresponding author
}

\section{Keywords}

Thrips, Mites, Aphids, Jassids, Whiteflies, Coccinellids, Spiders, Populations

Article Info

Accepted:

20 September 2018 Available Online: 10 October 2018

\section{A B S T R A C T}

Seasonal incidence of different sucking pests of chilli viz., thrips (Scirtothrips dorsalis Hood), mites (Polyphagotarsonemus latus Banks), Aphid (Aphis gossypii Glov.), Whitefly (Bemesia tabaci Genn.) and Jassids (Amrsca bigutula bigutula) and natural enemies like Coccinellids and spiders were worked out in the present study during 2016 at District Seed Farm (AB Block) of Bidhan Chandra Krishi Viswavidyalaya located at Kalyani, Nadia, West Bengal. Peak population of thrips was recorded to be in 18th standard week i.e. 12.58 per three leaves when the average temperature, relative humidity and weekly total rainfall were $31.20 \mathrm{c}, 66.79 \%$ and $17.8 \mathrm{~mm}$ respectively. For mite maximum population was recorded to be 28.55 per three leaves, when the average temperature, relative humidity and weekly total rainfall were recorded to be $31.040 \mathrm{C}, 74.29 \%$ and $71.1 \mathrm{~mm}$ respectively. Similarly for Aphids peak population attained by 17 th standard week i.e. 30.45 per three leaves when average temperature, relative humidity and weekly total rainfall were $33.760 \mathrm{C}, 67.29 \%$ and 0.0 $\mathrm{mm}$ respectively. Observation taken showed that whitefly incidence started from 1st standard week (0.44/three leaves) reaching a peak population in 44th standard week i.e. 6.22 per three leaves when the average temperature, relative humidity and weekly total rainfall were $27.720 \mathrm{C}, 84.00 \%$ and $7.4 \mathrm{~mm}$ respectively. Highest population of jassids reaching in 20th standard week i.e. 1.45 per three leaves when the average temperature, relative humidity and weekly total rainfall were $29.050 \mathrm{C}, 79.86 \%$ and $67.5 \mathrm{~mm}$ respectively. Regarding natural enemies the observation was taken as coccinellid beetle per plant and found that coccinellid population was at its peak during 43rd standard meteorological week i.e. 18.22 per plant when average temperature, relative humidity and weekly total rainfall were $28.290 \mathrm{C}, 80.07 \%$ and $0.0 \mathrm{~mm}$ respectively and Population of spiders were found to be maximum during 35th standard meteorological week i.e. 3.00 per plant when average temperature, relative humidity and weekly total rainfall were $29.060 \mathrm{C}, 61.57 \%$ and $16.2 \mathrm{~mm}$ respectively. 


\section{Introduction}

Chilli (Capsicum annuam L.) is an important spice crop as well as vegetable crop grown all over India. In India, chilli is cultivated in an area of 7.67 lakh hectares and the production is estimated at 12.34 lakh tones. Regular pest surveillance and monitoring their activity in relation to prevailing weather conditions is a quite essential step taken forward to evolve an effective and economically sound pest management programme. Among the different insect pests of chilli, aphid (Aphis gossypii Glov.), whitefly (Bemisia tabaci Genn.), thrips (Scirtothrips dorsalis Hood) mite (Polyphagotarsonemus latus Banks), and jassid (Amrasca bigutula bigutula.), were most important to cause substantial damage to chilli plant. Studies on population dynamics of pests and their relationship with meteorological parameters is a pre-requisite for formulation of pest management approach. In view of this, a regular surveillance and monitoring programme is essential to develop a forecasting system through manipulating interaction between crop phenology and insect incidence to avoid synchronization between peak period of pest infestation and vulnerable stage of crop growth. The relationship between the pests and prevailing weather conditions is a very important aspect of studies since knowledge of this relationship helps us to know the time of pest incidence as well as to take appropriate measures of pest control. But, this relationship is not simple, always due to they are multitude of different factors and their interactions. Most of the Conventional chemicals are broad spectrum, persistent in nature and having long residual action. The indiscriminate use of broad spectrum chemicals have resulted in reduction in biodiversity of natural enemies, outbreak of secondary pests and development of resistance to pesticides, pesticides induced resurgence and contamination of food and eco-system (Singh, 2000). So conservation of natural enemies like coccinellid beetles and spiders in the chilli ecosystem should be essential for sustainable management of insect pests of chilli.

\section{Materials and Methods}

\section{Location}

The experiment was conducted at the District Seed Farm (A-B Block) of Bidhan Chandra Krishi Viswavidyalaya located at Kalyani, Nadia, West Bengal in experimental field during the year 2016-2017. The geographical details of the site are $23^{\circ} \mathrm{N}$ latitude, $89^{\circ} \mathrm{E}$ longitude and 9.75 meter above mean sea level (MSL).

\section{Soil}

The soil of the experimental field was typically gangetic alluvial soil (Entisol) having sandy clay loam texture with good drainage facility, neutral in reaction and moderate in fertility

\section{Seasonal incidence of major insect pests of chilli}

\section{Season of experiment}

The present experiment was conducted during January, 2016 to January, 2017.

\section{Lay out of the experiment}

The experiment was conducted in a Randomized Block Design (RBD) with 3 replications and 8 treatments.

\section{Planting materials}

For the experiment, chilli cultivar named -Bullet (Capsicum annum var. annum L.; Family- Solanaceae) was considered which is a very common cultivar used by the farmers of 
West Bengal. Bullet Chillies are well known due to their bullet like shape and size, these are a Jalapeno type popular in Indian cuisine for the hot, light and fresh flavor.

Planting of crops for the incidence experiment have been taken 4 times for the year 2016 and reading of incidence has been taken throughout the year from active growth period of the crop.

\section{Recording of meteorological data}

The meteorological data on different abiotic factors viz. temperature (maximum \& minimum in ${ }^{\circ} \mathrm{C}$ ), relative humidity (maximum $\&$ minimum in \%), total rainfall (in $\mathrm{mm}$ ) wind speed $(\mathrm{Km} / \mathrm{hr})$, and bright sunshine hours (hr) during the period of investigation were collected from the AICRP on Agro meteorology, BCKV, Kalyani.

\section{Methodology}

Incidence of yellow mite, chilli, thrips, aphid, whitefly and jassid was recorded at an interval of 3 days. Pest counts were made from 3 top leaves of 5 randomly selected plants per plot. The leaves thus collected from the fields were put in a zip lock polypropelene bag and brought to the laboratory for observation under stereo- zoom binocular microscope (Olympus SZ-40) for estimation of population of thrips and mites. Observation of whitefly population was done by shaking the base of chilli plant and recording the number of whitefly through naked eye. Population of aphid, jassid and whitefly nymph was observed by using hand lens. Predators like coccinellid beetle and spider were recorded through naked eye.

Natural enemies namely spider and coccinelid predators (Coccinella septempunctata, Coccinella transversalis, Cheilomenes sexmaculata, Micraspis discolor) were also recorded for study the correlation between them and different weather factors.

\section{Statistical analysis}

Seasonal incidence of all the insect pests taken into consideration was recorded as insect count /three leaves at an interval of seven days whole round the year. The influence of different weather parameters like maximum temperature, minimum temperature, Maximum relative humidity, Minimum relative humidity and sunshine hours on population dynamics of, thrips, aphid, whitefly, jassid and naturally occurring predators had been investigated through correlation studies, calculating respective - $r$ (correlation coefficient) through Pearsons correlation.

\section{Results and Discussion}

\section{Seasonal incidence of thrips (Scirtothrips dorsalis Hood)}

Observations recorded from thrips/three leaf states that first incidence of population was recorded from $1^{\text {st }}$ week of January and it was nearly constant upto $4^{\text {th }}$ standard week and then the population declined gradually upto $8^{\text {th }}$ standard week. Peak population was recorded to be in $18^{\text {th }}$ standard week i.e., $12.58 /$ three leaves when the average temperature, relative humidity and weekly total rainfall were 31.2 0c, $66.79 \%$ and $17.8 \mathrm{~mm}$ respectively. The lowest population recorded was found in $5^{\text {th }}$ standard meteorological week i.e., 0.11/ 3 leaf when the average temperature, relative humidity and weekly total rain fall were 21.52 ${ }^{0} \mathrm{C}, 70.50 \%$ and $0.0 \mathrm{~mm}$ respectively.

Correlation studies (Table 1) between thrips population and weather parameters revealed that population of thrips showed significant positive correlation with average temperature, maximum and minimum temperature and a 
significant negative correlation with maximum relative humidity while non-significant positive correlation with temperature difference and non-significant negative correlation with relative humidity (minimum and average) and weekly rainfall. This can be inferred as activity of thrips population increases with high temperature, high relative humidity and decreases with rainfall but population increases with the rise of temperature difference. The results were confirmed by Bhede et al., (2008) and Patel et al., (2009) (Fig. 1).

\section{Seasonal incidence of (Polyphagotarsonemus latus Banks)}

Mite

Population studies on mites observed as mite/three leaves stated that the mite infestation started from $1^{\text {st }}$ SMW (1.00 mites/ three leaves) and the population tends to remain at a range of 1-6 mites/three leaves upto $7^{\text {th }}$ SMW. A drastic increase in population was noticed in $8^{\text {th }}$ SMW (12.22 mites/ three leaves) and then gradually declined upto $10^{\text {th }} \mathrm{SMW}$. Then mite population suddenly increased from $13^{\text {th }}$ SMW upto $19^{\text {th }} \mathrm{SMW}$, where peak population was recorded to be 28.55/three leaves, when the average temperature, relative humidity and weekly total rainfall were recorded to be $31.04^{\circ} \mathrm{C}, 74.29 \%$ and $71.1 \mathrm{~mm}$ respectively. It was followed by gradually decline in population upto $25^{\text {th }} \mathrm{SMW}$, leading to lowest recorded population i.e. 0.11/three leaves.

Correlation studies (Table 2) between mites population and weather parameters revealed that mites population showed a significant positive correlation with temperature difference, maximum temperature and average temperature while it showed significant negative correlation with relative humidity (maximum, minimum, average). A nonsignificant negative correlation was found between mite population and weekly total rainfall. The population of mites showed a non-significant positive correlation with minimum temperature. This inference drawn from correlation studies gives a account of mite population to increase with high temperature and temperature difference, while decreases with high relative humidity and heavy weekly total rainfall. The result was confirmed by Lingeri et al., (1998), Bhede and Vosle (2008), Patil et al., (2009) and Chaven et al., (2003) (Fig. 2).

\section{Seasonal incidence of Aphid (Aphis gossypii Glov.)}

The incidence of aphid started from $1^{\text {st }}$ standard week i.e. 1.22 per three leaves; with peak population attained by $17^{\text {th }}$ standard week i.e. 30.45 per three leaves when average temperature, relative humidity and weekly total rainfall were $33.76^{\circ} \mathrm{C}, 67.29 \%$ and 0.0 $\mathrm{mm}$ respectively. Again population gradually declined from $18^{\text {th }}$ to 26th standard week attaining lowest population in $33^{\text {rd }}$ standard week. It is notably observed there was no incidence of aphids during $38^{\text {th }}$ and $39^{\text {th }}$ standard week (Fig. 3).

Correlation studies revealed that the aphid population had a non-significant positive correlation with temperature difference while non-significant negative correlation with rainfall (weekly total) and relative humidity (minimum, average). On the contrary it showed significant positive correlation with temperature (maximum, minimum, average) while showed significant negative correlation with maximum relative humidity (Table 3 ).

This indicates that activity of aphid population increases with increase in maximum, minimum and average temperature and decreases with rainfall. The pest population decreases under warm humid conditions. This result is also similar with the findings of Meena et al., (2013) and Butani (1970). 
Table.1 correlation co-efficient between thrips and weather parameters

\begin{tabular}{|c|c|c|c|c|}
\hline & & \multirow[t]{2}{*}{ Correlation co- } & \multirow{2}{*}{$\begin{array}{l}\text { Co-efficient of } \\
\text { determination }\end{array}$} & \multirow[b]{2}{*}{ Regression equation } \\
\hline \multicolumn{2}{|c|}{ Environmental parameter } & & & \\
\hline & & \multirow[t]{2}{*}{ efficient (r) } & & \\
\hline & & & $\left(\mathbf{R}^{2}\right)$ & \\
\hline \multirow[t]{4}{*}{ Temperature ${ }_{0} \mathrm{C}$} & Maximum & $0.652 * *$ & 0.426 & $Y=0.757 x+28.86$ \\
\hline & Minimum & $0.361 * *$ & 0.130 & $Y=0.594 x+19.47$ \\
\hline & Difference & 0.157 & 0.037 & $Y=0.214 x+8.84$ \\
\hline & Average & $0.511 * *$ & 0.181 & $Y=0.727 x++23.58$ \\
\hline Relative Humidity & Maximum & $(-) 0.352^{*}$ & 0.124 & $Y=0.346 x+94.90$ \\
\hline \multirow[t]{2}{*}{$(\%)$} & Minimum & $(-) 0.145$ & 0.021 & $Y=-0.663 x+65.92$ \\
\hline & Average & $(-) 0.186$ & 0.035 & $Y=-0.504 x+80.41$ \\
\hline Weekly rainfall (mm) & Total & $(-) 0.114$ & 0.013 & $Y=1.501 x++36.75$ \\
\hline
\end{tabular}

* Significant at $5 \%$ level of significance

$* *$ Significant at $1 \%$ level of significance

Table. 2 Correlation co-efficient between mite and weather parameters

\begin{tabular}{|c|c|c|c|c|}
\hline & & Correlation & Co-efficient of & Regression \\
\hline \multirow{2}{*}{\multicolumn{2}{|c|}{ Environmental parameter }} & \multirow[t]{2}{*}{ co-efficient } & \multirow[t]{2}{*}{ determination } & \\
\hline & & & & Equation \\
\hline & & (r) & $\left(\mathbf{R}_{2}\right)$ & \\
\hline & Maximum & $0.693 * *$ & 0.480 & $y=0.291 x+29.24$ \\
\hline \multirow[t]{3}{*}{ Temperature ${ }_{0} \mathrm{C}$} & Minimum & 0.267 & 0.071 & $Y=0.159 x++20.44$ \\
\hline & Difference & $0.352 *$ & 0.123 & $y=0.132 x++8.81$ \\
\hline & Average & $0.469 * *$ & 0.220 & $Y=0.225 x+24.84$ \\
\hline \multirow[t]{2}{*}{ Relative Humidity } & Maximum & $(-) 0.478 * *$ & 0.228 & $y=-0.170 x+95.08$ \\
\hline & Minimum & $(-) 0.395 * *$ & 0.156 & $Y=-0.656 x+69.46$ \\
\hline$(\%)$ & Average & $(-) 0.422 * *$ & 0.178 & $Y=-0.413 x+82.27$ \\
\hline Weekly rainfall(mm) & Total & $(-) 0.241$ & 0.058 & $Y=-1.152 x+41.53$ \\
\hline
\end{tabular}

*Significant at $5 \%$ level of significance

**Significant at $1 \%$ level of significance 
Table.3 Correlation co-efficient between aphid and weather parameters

\begin{tabular}{|c|c|c|c|c|}
\hline & & Correlation & Co-efficient of & \multirow{2}{*}{ Regression } \\
\hline Environmental parameter & & co-efficient & determination & \\
\hline & & $(\mathbf{r})$ & $\left(\mathbf{R}_{2}\right)$ & Equation \\
\hline & Maximum & $0.614^{* *}$ & 0.377 & $\mathrm{Y}=0.251 \mathrm{x}+30.39$ \\
\hline Temperature $\mathbf{0}$ & Minimum & $0.351^{*}$ & 0.113 & $\mathrm{Y}=0.217 \mathrm{x}+20.32$ \\
\hline & Difference & 0.130 & 0.016 & $\mathrm{Y}=0.047 \mathrm{x}+9.77$ \\
\hline Relative Humidity & Average & $0.487^{* *}$ & 0.237 & $\mathrm{Y}=0.227 \mathrm{x}+25.51$ \\
\hline & Maximum & $(-) 0.409^{* *}$ & 0.167 & $\mathrm{Y}=-0.142 \mathrm{x}+94.38$ \\
\hline & Minimum & $(-) 0.165$ & 0.027 & $\mathrm{Y}=-0.267 \mathrm{x}+64.89$ \\
\hline & Average & $(-) 0.214$ & 0.006 & $\mathrm{Y}=-0.115 \mathrm{x}+77.61$ \\
\hline Weekly rainfall (mm) & Total & $(-) 0.017$ & 0.000 & $\mathrm{Y}=-0.083 \mathrm{x}+30.95$ \\
\hline
\end{tabular}

*Significant at $5 \%$ level of significance

**Significant at $1 \%$ level of significance

Table.4 Correlation co-efficient between whitefly and weather parameters

\begin{tabular}{|c|c|c|c|c|}
\hline & & Correlation & Co-efficient of & Regression \\
\hline Environmental parameter & & co-efficient & determination & \\
\hline & & $(\mathbf{r})$ & $\left(\mathbf{R}_{2}\right)$ & Equation \\
\hline & Maximum & $(-) 0.109$ & 0.012 & $\mathrm{Y}=-0.256 \mathrm{x}+32.48$ \\
\hline Temperature $\mathbf{0}$ & Minimum & $(-) 0.295^{*}$ & 0.098 & $\mathrm{Y}=-1.018 \mathrm{x}++23.82$ \\
\hline & Difference & $0.345^{*}$ & 0.119 & $\mathrm{Y}=0.726 \mathrm{x}+8.89$ \\
\hline Relative Humidity & Average & $(-) 0.231$ & 0.053 & $\mathrm{Y}=-0.620 \mathrm{x}+28.03$ \\
\hline & Maximum & $(-) 0.097$ & 0.009 & $\mathrm{Y}=-0.193 \mathrm{x}+93.75$ \\
\hline & Minimum & $(-) 0.215$ & 0.046 & $\mathrm{Y}=-1.990 \mathrm{x}++66.37$ \\
\hline Weekly rainfall (mm) & Average & $(-) 0.199$ & 0.039 & $\mathrm{Y}=-1.092 \mathrm{x}+80.06$ \\
\hline
\end{tabular}

* Significant at $5 \%$ level of significance

**Significant at $1 \%$ level of significance 
Table.5 Correlation co-efficient between jassid and weather parameters

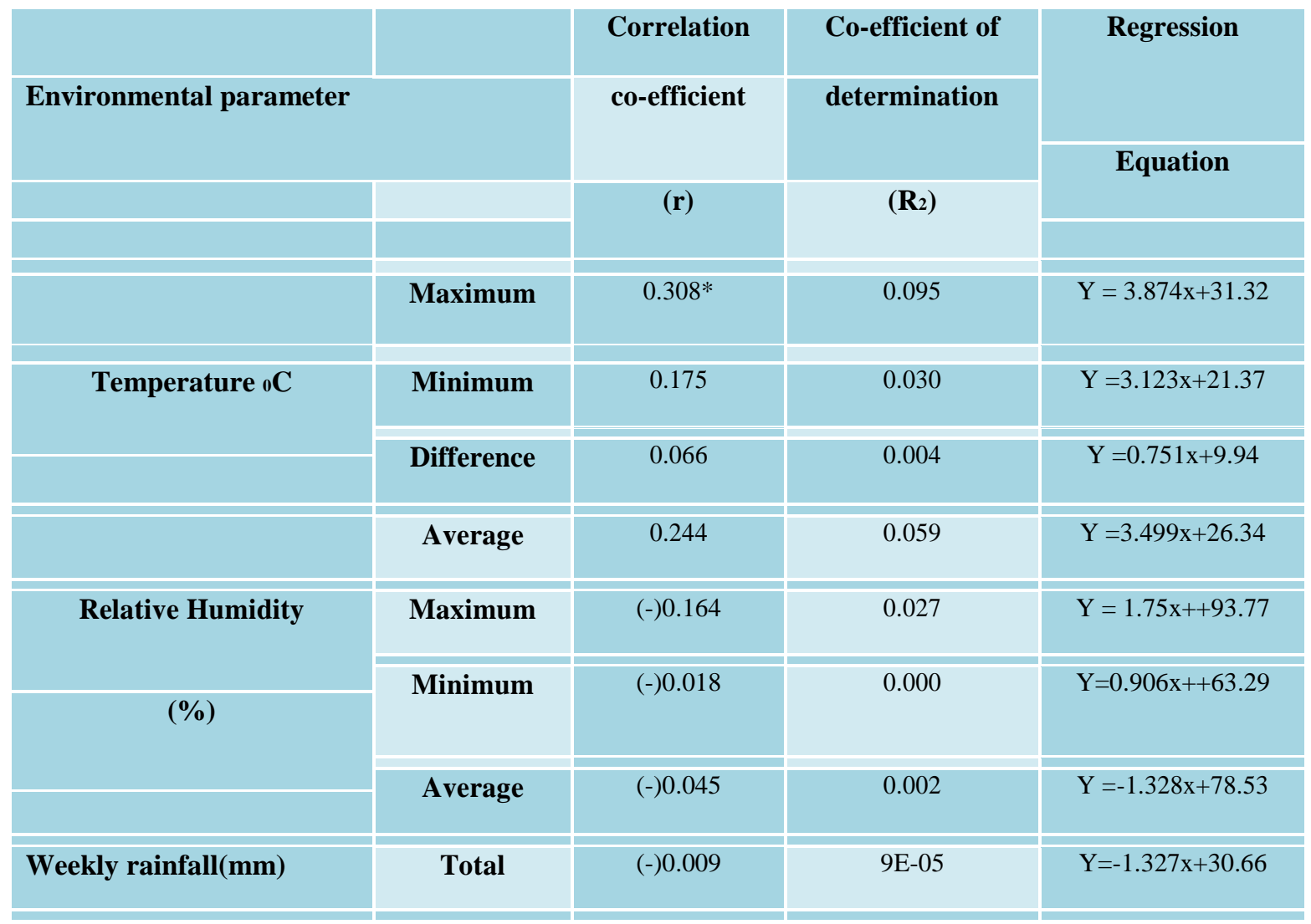

*Significant at $5 \%$ level of significance

$* *$ Significant at $1 \%$ level of significance

Table.6 Correlation co-efficient between ladybird beetle and weather parameters

\begin{tabular}{|c|c|c|c|c|}
\hline & & Correlation & Co-efficient of & Regression \\
\hline \multicolumn{2}{|c|}{ Environmental parameter } & \multirow{2}{*}{$\begin{array}{c}\text { co-efficient } \\
\text { (r) }\end{array}$} & \multirow{2}{*}{$\begin{array}{c}\text { determination } \\
\qquad\left(\mathbf{R}_{2}\right)\end{array}$} & \multirow[b]{2}{*}{ Equation } \\
\hline & & & & \\
\hline & Maximum & $0.349 *$ & 0.122 & $Y=0.277 x+30.77$ \\
\hline \multirow[t]{3}{*}{ Temperature ${ }_{0} \mathrm{C}$} & Minimum & 0.130 & 0.017 & $Y=0.146 x+21.29$ \\
\hline & Difference & 0.183 & 0.033 & $Y=0.130 x+9.47$ \\
\hline & Average & 0.234 & 0.054 & $Y=0.211 x+26.03$ \\
\hline Relative Humidity & Maximum & 0.126 & 0.000 & $Y=0.011 x+93.49$ \\
\hline \multirow{2}{*}{$(\%)$} & Minimum & $(-) 0.131$ & 0.017 & $Y=-0.412 x+65.04$ \\
\hline & Average & $(-) 0.114$ & 0.013 & $Y=-0.211 x+79.27$ \\
\hline Weekly rainfall (mm) & Total & $(-) 0.251^{*}$ & 0.063 & $Y=-2.257 x+40.96$ \\
\hline
\end{tabular}

*Significant at $5 \%$ level of significance

$* *$ Significant at $1 \%$ level of significance 
Table.7 Correlation co-efficient between spider and weather parameters

\begin{tabular}{|c|c|c|c|c|}
\hline & & Correlation & Co-efficient of & Regression \\
\hline \multicolumn{2}{|c|}{ Environmental parameter } & co-efficient & determination & \\
\hline & & \multirow[b]{2}{*}{ (r) } & \multirow[b]{2}{*}{$\left(\mathbf{R}_{2}\right)$} & \\
\hline & & & & \\
\hline & Maximum & $(-) 0.114$ & 0.013 & $Y=-0.628 x+32.68$ \\
\hline \multirow[t]{3}{*}{ Temperature ${ }_{0} \mathrm{C}$} & Minimum & 0.117 & 0.013 & $Y=0.911 x+21.08$ \\
\hline & Difference & $(-) 0.313^{*}$ & 0.098 & $Y=-1.540 x+11.59$ \\
\hline & Average & 0.022 & 0.000 & $\mathrm{Y}=0.141 \mathrm{x}+26.88$ \\
\hline Relative Humidity & Maximum & 0.145 & 0.021 & $Y=0.675 x+92.77$ \\
\hline \multirow[t]{2}{*}{$(\%)$} & Minimum & 0.149 & 0.022 & $Y=3.227 x+59.95$ \\
\hline & Average & 0.152 & 0.023 & $Y=1.951 x+76.36$ \\
\hline Weekly rainfall (mm) & Total & 0.201 & 0.040 & $\mathrm{Y}=12.51 \mathrm{x}+18.13$ \\
\hline
\end{tabular}

*Significant at $5 \%$ level of significance

**Significant at $1 \%$ level of significance

Fig.1 Incidence of thrips as influenced by temperature, humidity and total rainfall during 2016

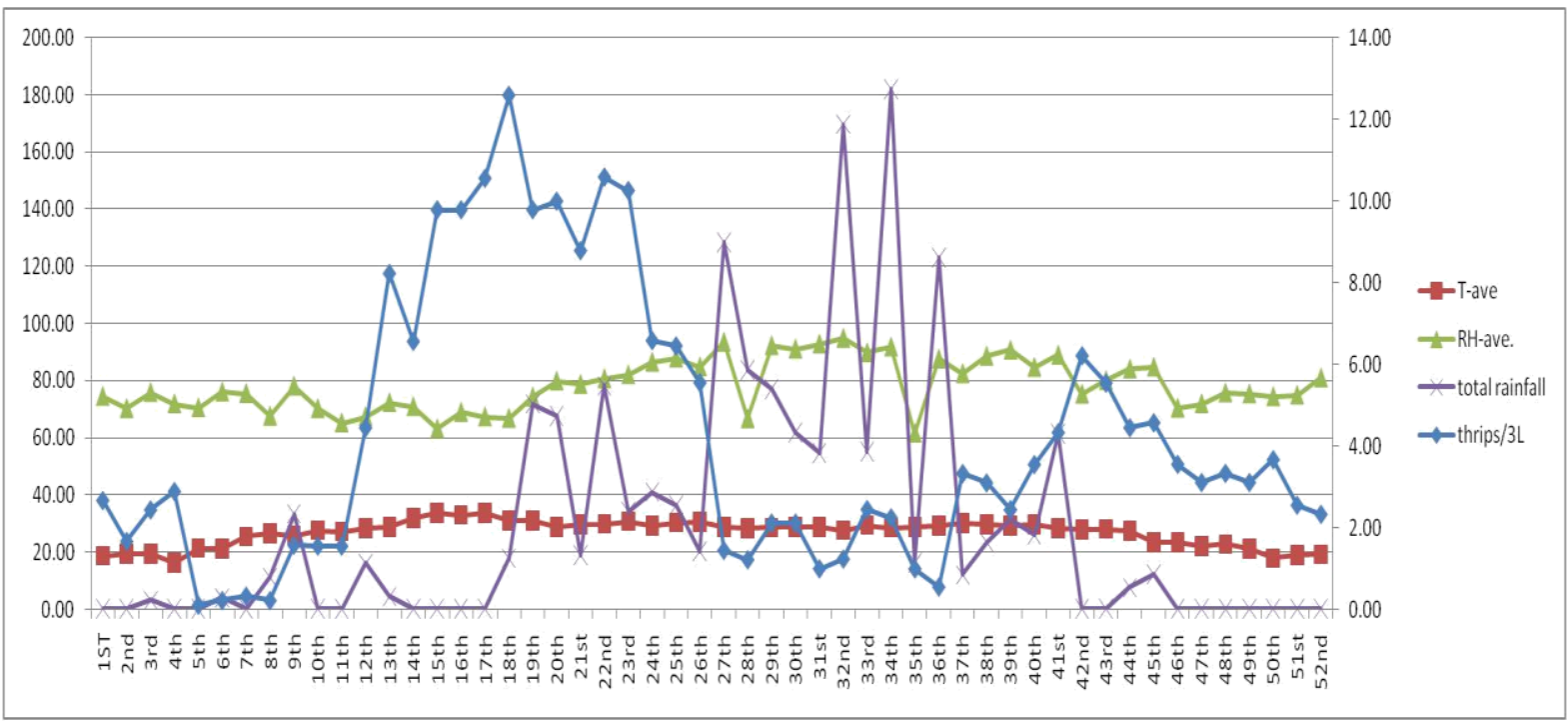


Fig.2 Incidence of mite as influenced by temperature, humidity and total rainfall during 2016

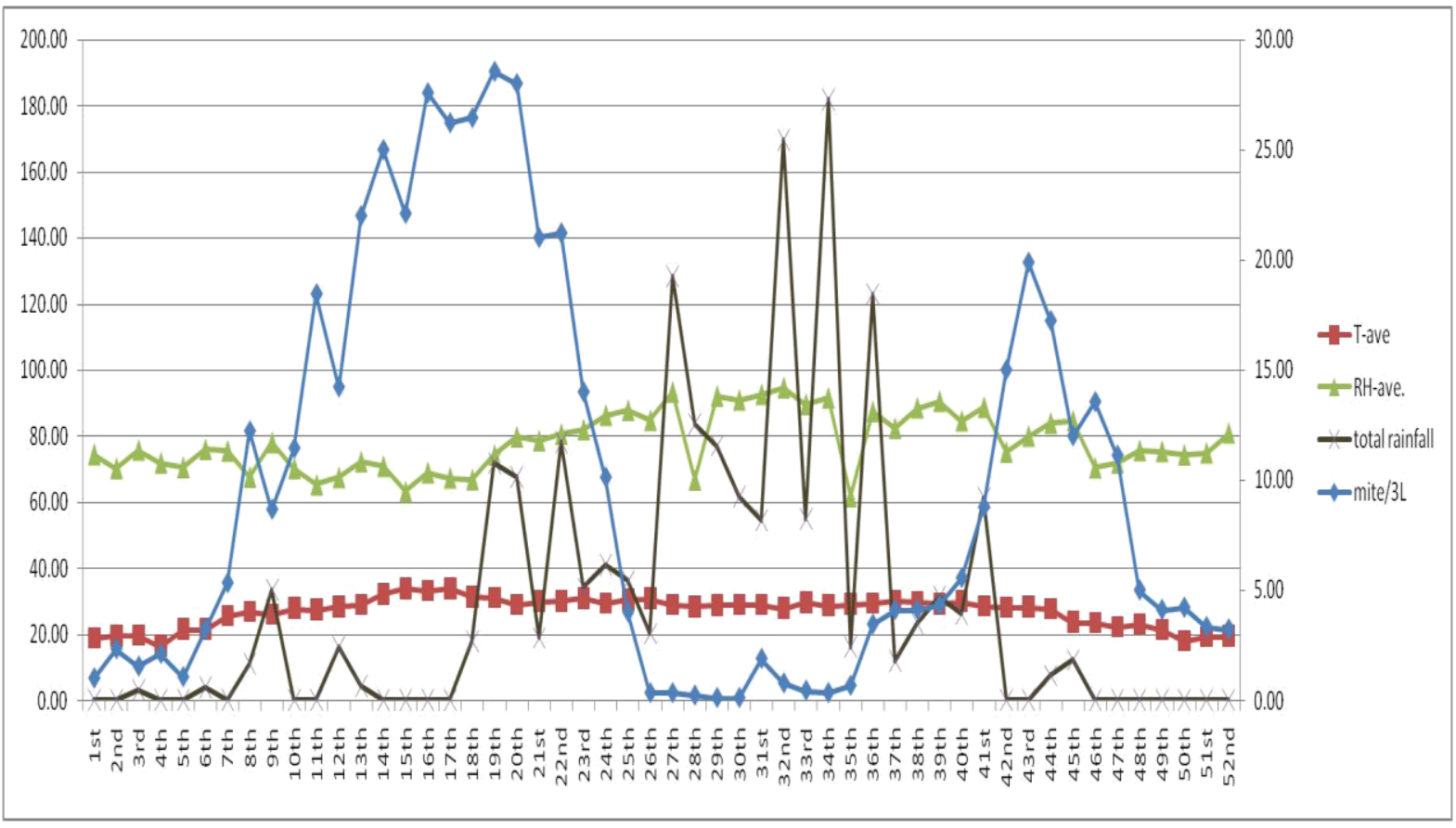

Fig.3 Incidence of aphid as influenced by temperature, humidity and total rainfall during 2016

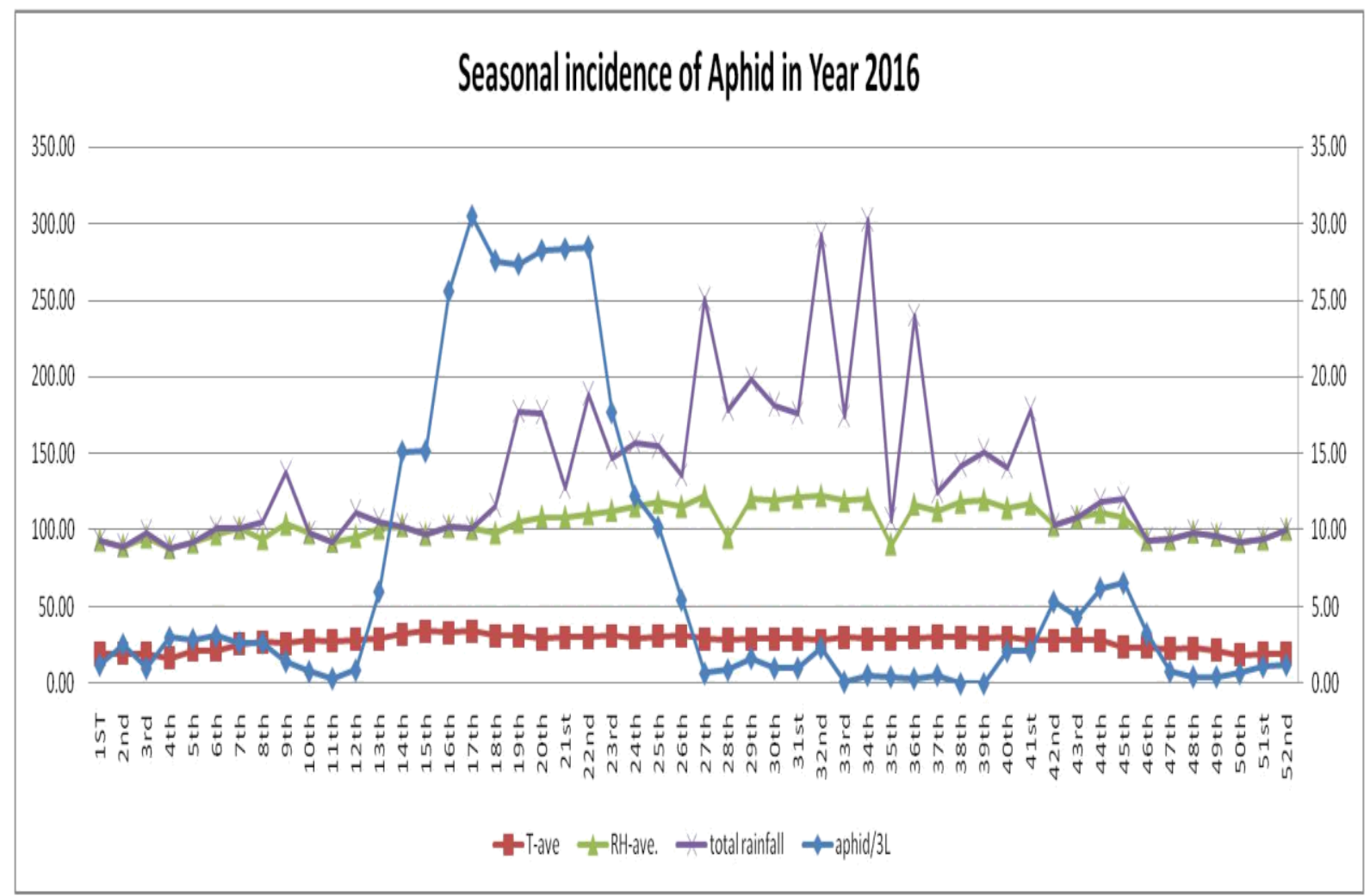


Fig.4 Incidence of whitefly as influenced by temperature, humidity and total rainfall during 2016

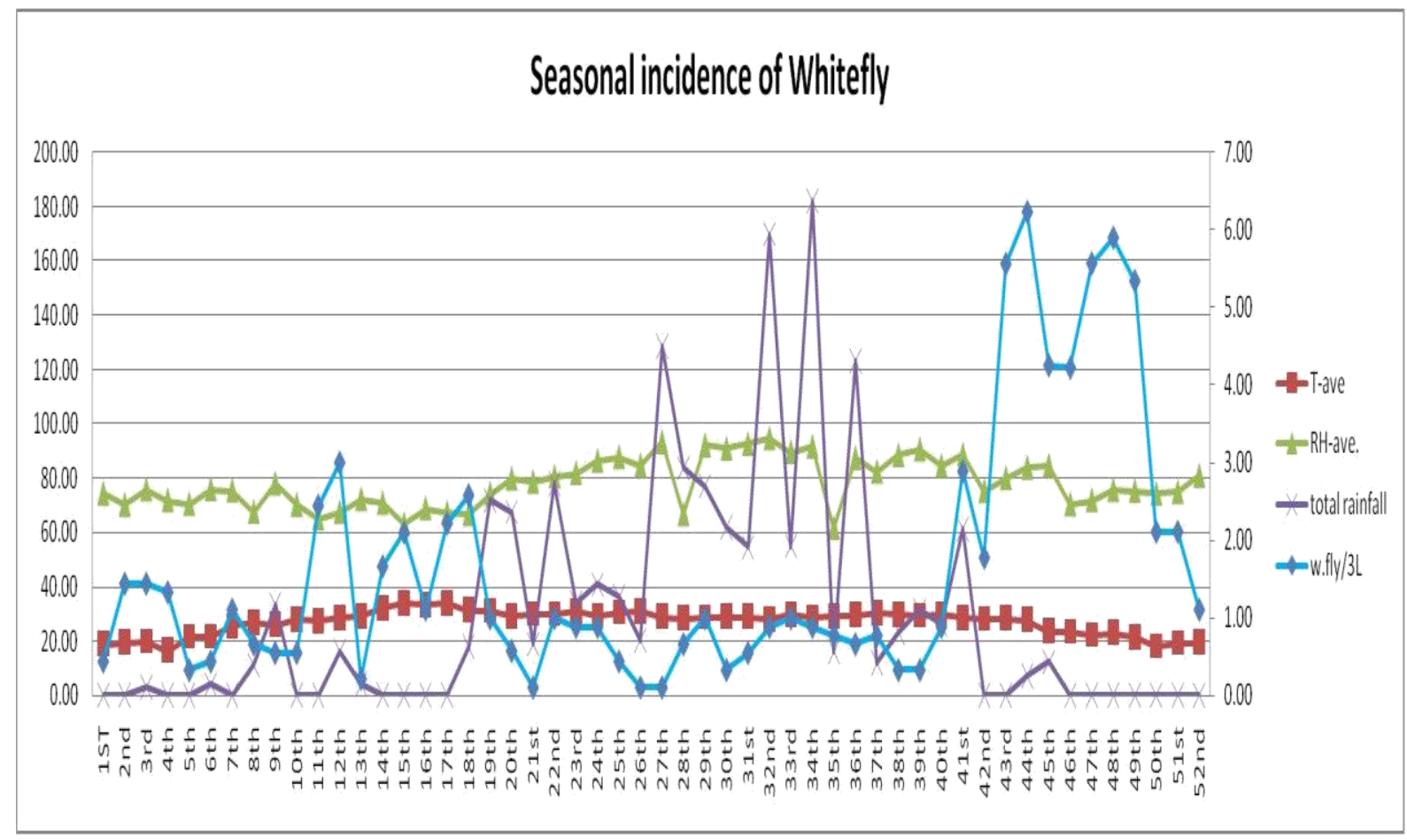

Fig.5 Incidence of jassid as influenced by temperature, humidity and total rainfall during 2016

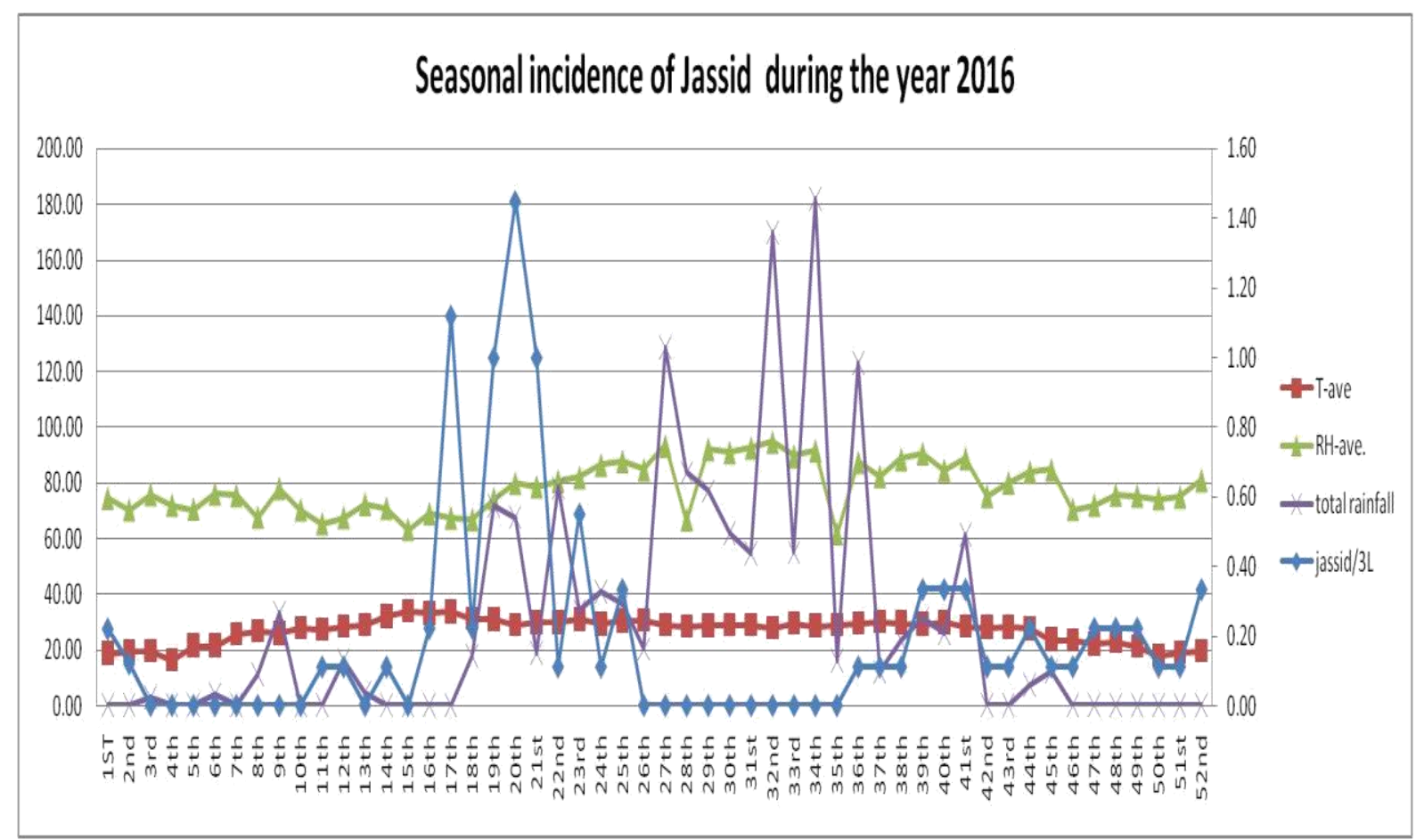


Fig.6 Incidence of coccinellid as influenced by temperature, humidity and total rainfall during 2016

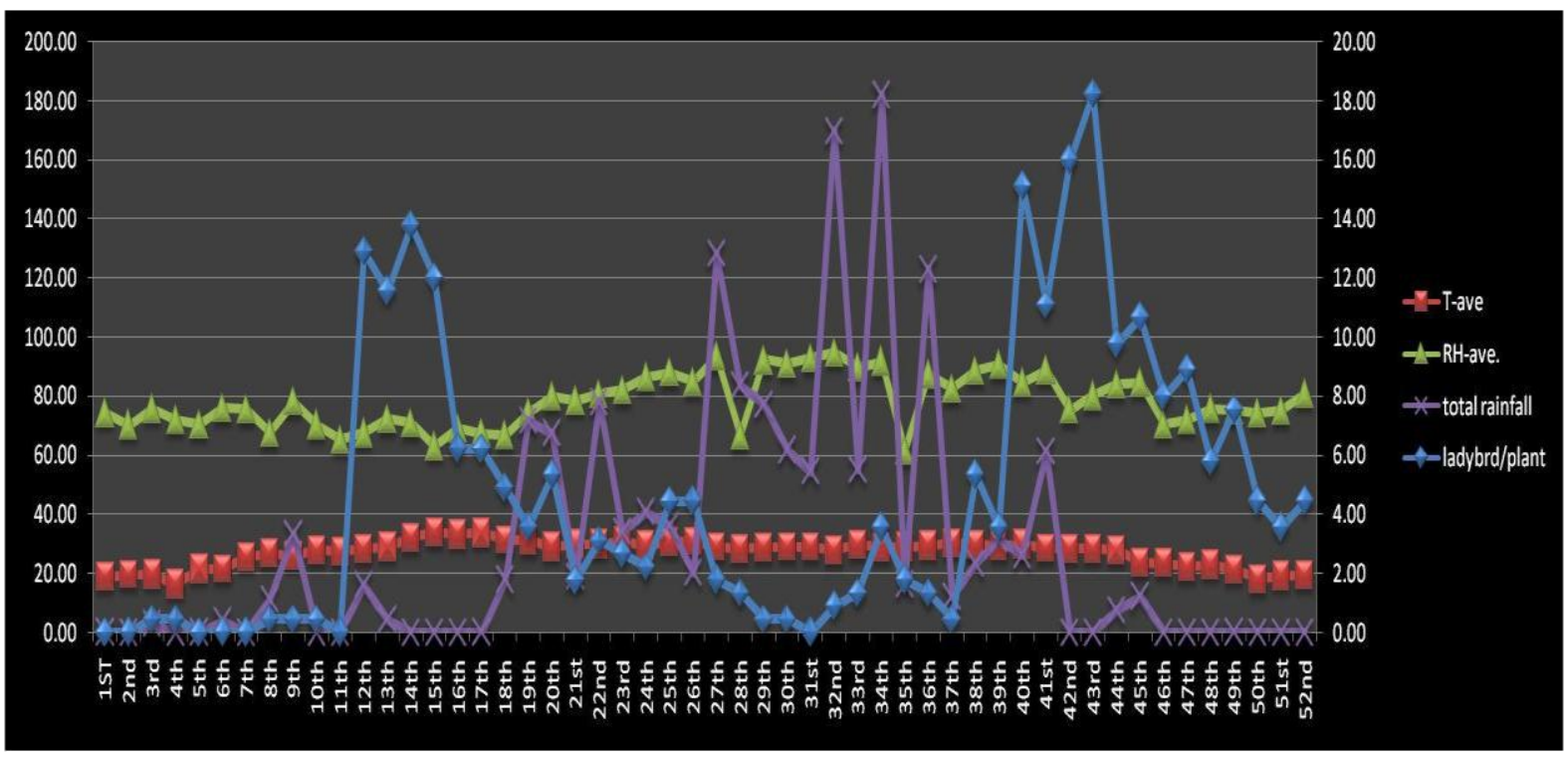

Fig.7 Incidence of spider as influenced by temperature, humidity during 2016

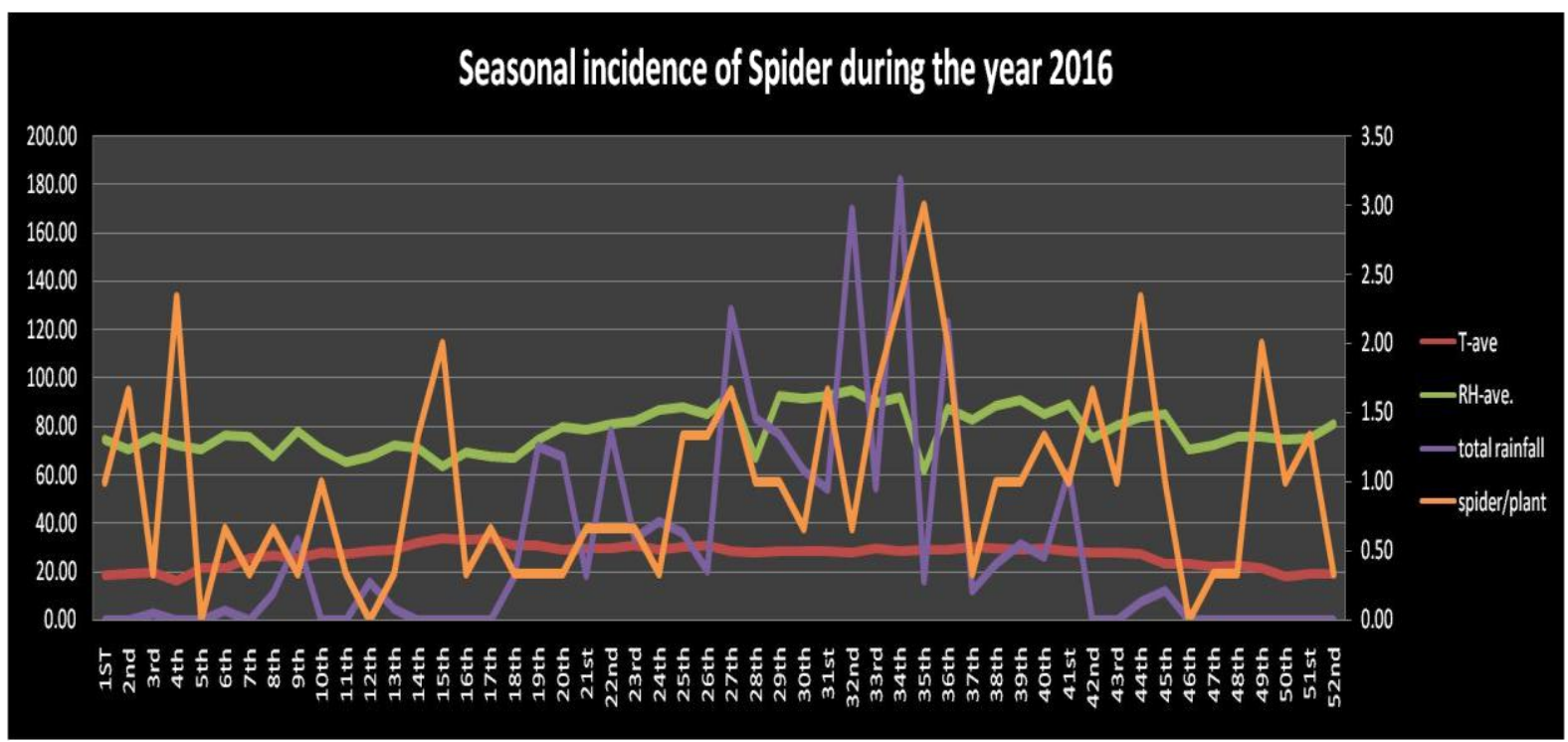

\section{Seasonal incidence of Whitefly (Bemesia tabaci Genn.)}

Observation taken showed that whitefly incidence started from $1^{\text {st }}$ standard week (0.44/three leaves) reaching a peak population in $44^{\text {th }}$ standard week i.e. 6.22 per three leaves when the average temperature, relative humidity and weekly total rainfall were $27.72^{\circ} \mathrm{C}, 84.00 \%$ and $7.4 \mathrm{~mm}$ respectively.. Lowest Population was attained during $21^{\text {st }}$, $26^{\text {th }}$ and $27^{\text {th }}$ standard week i.e. 0.11 whitefly per three leaves (Fig. 4).

Correlation studies (Table 4) between whitefly population and weather parameters revealed that whitefly population showed significant positive correlation with 
temperature difference while significant negative correlation with minimum temperature and weekly total rainfall. On the contrary non-significant negative correlation was found between whitefly populations and temperature (maximum, average) and relative humidity (maximum, minimum, average).

This indicates that activity of whitefly decrease with relative humidity, decrease in temperature and rainfall. This result is also similar with the findings of Khalid et al., (2009).

\section{Seasonal incidence of jassid (Amrsca bigutula bigutula)}

Observations taken as jassid/three leaves revealed that infestation was started from $1^{\text {st }}$ standard week $(0.22 /$ three leaves $)$ with the peak population reaching in $20^{\text {th }}$ standard week i.e 1.45 per three leaves when the average temperature, relative humidity and weekly total rainfall were $29.05^{\circ} \mathrm{C}, 79.86 \%$ and $67.5 \mathrm{~mm}$ respectively. It also states that the jassid population was found to be less or negligible in the whole year (Fig. 5).

Correlation studies (Table 5) between jassid population and weather parameter revealed that the population of jassids showed a significant positive correlation with maximum temperature while non-significant negative relation correlation with relative humidity (maximum, minimum, average) and weekly total rainfall.

On the contrary there was a non-significant positive correlation found between jassid population with temperature difference, minimum temperature and average temperature. This can be inferred that activity of jassids increases with temperature and decreases with heavy rains. The result is similar with the findings of Saini et al., (2017).
Seasonal incidence of natural enemies present in chilli ecosystem coccinellids

Ladybird beetle is important biological agent of chilli pests assisting to reduce the damage of insect infestation appeared in the year 2016. Its occurrence and degree of infestation varied with season to season. The observation was taken as coccinellid beetle per plant and found that coccinellid population was at its peak during $43^{\text {rd }}$ standard meteorological week i.e 18.22 per plant when average temperature, relative humidity and weekly total rainfall were $28.29^{\circ} \mathrm{C}, 80.07 \%$ and 0.0 $\mathrm{mm}$ respectively. Population was negligible during $1^{\text {st }}, 2^{\text {nd }}, 5^{\text {th }}, 6^{\text {th }}, 7^{\text {th }}, 22^{\text {nd }}$ and $31^{\text {st }}$ standard week (Fig. 6).

Correlation studies (Table 6) between ladybird beetle population and weather parameters revealed that ladybird beetle population had a non-significant positive correlation with temperature difference, minimum temperature, average temperature and maximum relative humidity while nonsignificant negative correlation with relative humidity (minimum and average). A significant positive correlation found between coccinellid population and maximum temperature and significant negative correlation of coccinellid population with weekly total rainfall was reported.

\section{Spider}

Spider is an important predator of tomato plant and become active throughout the year. Incidence of predator activity studied in the year 2016. Population of spiders was found to be maximum during $35^{\text {th }}$ standard meteorological week i.e. 3.00 per plant when average temperature, relative humidity and weekly total rainfall were $29.06^{\circ} \mathrm{C}, 61.57 \%$ and $\quad 16.2 \mathrm{~mm}$ respectively (Fig. 7). Abundance of spiders was found to be negligible during $5^{\text {th }}, 12^{\text {th }}$ and $46^{\text {th }}$ standard meteorological week. 
Correlation studies (Table 7) between spider population and environmental parameter revealed that spider population had a significant negative correlation with temperature difference. On the other hand non-significant negative correlation found between spider population and maximum temperature and non-significant positive correlation between spider and temperature (minimum, average), relative humidity (maximum, minimum, average) and weekly total rainfall.

\section{References}

Anonymous. (2012). www.faostat.com.

Anonymous. (2012a). Spice board of India.

Anonymous. (2013a). Indian Horticulture Database. National Horticulture Board. pp 6.

Bhede, B.V., Bhosle, B.B. and More, D.G. (2008a). Influence of meteorological factors over the incidence of chilli mite, Polyphagotarsonemus latus and its chemical control strategies. Indian Journal of Plant Protection, 36(2): 200203.

Bhede, B.V., Suryawanshi, D.S. and More, D.G. (2008b). Population dynamics and bioefficacy of newer insecticides against chilli thrips, Scirtothrips dorsalis (Hood). Indian Journal of Entomolgy, 70(3): 22.

Butani, D. K. (1970). Insect Pests of fruit crops, citrus. Pesticides. 7: 23-26.

Chavan, B.P., Kadam, J.R. and Koli, H.R. (2003). Effects of dates of sowing on incidence of red spider mite,
Tetranychus cinnabarinus (Boisd) infesting okra. Proceeding of State Level Seminar on Pest Management for Sustainable Agriculture. February, 6-7, 2003.

Khalid, S.A.N., Roff, M.N.M. and Idris, A.B. (2009). Population abundance of alate whitefly, (Bemisia tabaci Gennadius) in chilli (Capsicum annuum L.) ecosystem. Journal of Tropical Agriculture and Food Science, 37(2): 263-270.

Lingeri, M.S., Awaknavar, T.S., Lingappa, S. and Kulkarni, K.A. (1998). Seasonal occurance of Chilli Mite (Polyphagotarsonemus latus Banks) and thrips (Scirtothrips dorsalis (Hood). Karnataka Journal of Agricultural Science, 11(2): 380-385.

Meena. R.S., Ameta. O.P. and Meena, B.L. (2013). Population dynamics of sucking pests and their correlation with weather parameters in chilli, Capsicum annum L. crop. The Bioscan, 8(1): 177-180.

Patel, B.H., Koshiya, D.J. and Korat, D.M. (2009). Population dynamics of chilli thrips, Scirtothrips dorsalis Hood in relation to weather parameters. Karnataka Journal of Agricultural Sciences, 22(1): 108-110.

Saini, A., Ahir, K.C., Rana, B.S. and Kumar, R. (2017). Population dynamics of sucking pests infesting chilli (Capsicum annum L.). Journal of Entomology and Zoology Studies, 5(2): 250-252.

Singh, S.P. (2000). Bio Intensive approach Helpful. The Hindu Survey of Indian Agriculture: 159-163.

\section{How to cite this article:}

Subhashree Priyadarshini, Ashima Mishra, Anjan Kumar Nayak and Pavan Thakoor. 2018. Seasonal Incidence of Different Sucking Pests of Chilli and their Natural Enemies under West Bengal Condition. Int.J.Curr.Microbiol.App.Sci. 7(10): 2936-2948. doi: https://doi.org/10.20546/ijcmas.2018.710.341 